\begin{tabular}{ll}
\hline CURRENT & ISSN: 0973-4929, Vol. 16, No. (3) 2021, Pg. 989-1000 \\
WORLD & Current World Environment
\end{tabular}

ENVIRONMENT

www.cwejournal.org

\title{
Variations in Vegetation and Nutrient Composition in Sal and Eucalyptus Stands: A Case Study of Bhagabatichak Forest Area, West Bengal, India
}

\section{TRIDIB KUMAR SAHOO}

Department of Botany, Tamralipta Mahavidyalaya, Tamluk, Purba-Medinipur. West Bengal, India.

\section{Abstract}

The study was conducted on two type of stands one was coppice sal (Shorea robusta Gaertn. F.) stand (CSS) managed by Forest Protection Committee (FPC) along with the State Forest Department and other was coppice eucalyptus (Eucalyptus tereticornis Sm.) stand (CES) solely managed by the State Forest Department. These two stands are in Bhagabatichak forest area under Midnapore East Forest Division, West Bengal, India. In this study Importance Value Index (IVI), biomass, species diversity index $(H /)$, concentration of dominance $(C d)$, species richness index $(d)$, beta diversity $(\beta d)$, index of similarity (IS), nutrient composition and soil $\mathrm{pH}$ of the two stands were measured. The study reveals that the highest numbers of species were available during monsoon period in both the stands; these were 71 and 43 respectively in CSS and CES. The result also shows that the highest IVI was occupied by sal in CSS and eucalyptus in CES in all the seasons. Other major species were Clerodendrum viscosum Vent, Lantana camara L., Combretum roxburghii Spreng. Highest diversity index $(\mathrm{H} /)$ was in CSS during monsoon (1.983) and minimum in CES during pre-monsoon (1.274). So, the species richness index (d) was higher in CSS during monsoon (28.259) and lower in CES during pre-monsoon (12.112). Cd shows the opposite trend, it was higher in CES during pre-monsoon (0.125) and lower in CSS during monsoon (0.042). $\beta$ diversity reflects the rate of species change, which was highest in CSS during post-monsoon (1.300). The similarity index (IS) between the two stands was $64.91 \%$. The total annual above ground biomass (agb) were $87008.043 \mathrm{~kg} \mathrm{ha}^{-1} \mathrm{yr}^{-1}$ in CSS and $86309.837 \mathrm{~kg} \mathrm{ha}^{-1}$ $\mathrm{y}^{-1}$ in CES. Among them major contributors were sal (82357.946 kg ha-1 $\mathrm{yr}^{-1}$ ) in CSS and eucalyptus (84246.358 $\mathrm{kg} \mathrm{ha}^{-1} \mathrm{yr}^{-1}$ ) in CES. In both the stands higher amount of nutrients were available in Combretum roxburghii. In CSS

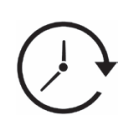

Article History

Received: 04 August 2021 Accepted: 15 December 2021

\section{Keywords}

Eucalyptus Stand; Importance Value Index (Ivi); Sal Stand; Species Diversity.

CONTACT Tridib Kumar Sahoo $\backslash$ tksahoo.botany@gmail.com 9 Department Of Botany, Tamralipta Mahavidyalaya, Tamluk, Purba-Medinipur. W.b. , India.

\section{(c) (i)}

(C) 2021 The Author(s). Published by Enviro Research Publishers.

This is an Open Access article licensed under a Creative Commons license: Attribution 4.0 International (CC-BY).

Doi: http://dx.doi.org/10.12944/CWE.16.3.28 
available NPK were $1.272 \%, 0.527 \%$ and $1.867 \%$ respectively in Combretum roxburghii. In CES the values were $0.864 \%, 0.513 \%$ and $1.724 \%$ respectively for the same species. Soil pH of CSS were 5.53 in top soil and 5.79 in subsoil, in CES soil pH were 4.88 and 5.02 in top soil and subsoil respectively. It was observed that sal stand was better than eucalyptus stand with respect to ecology and biodiversity.

\section{Introduction}

Forest represents the largest and most natural plant community. Though, today some woody plant species like Eucalyptus sp., Acacia sp., Dalbergia $\mathrm{sp}$. are planted by human being for their economical need. This type of stands has traditionally been seen as a source of timber. ${ }^{1}$ The return from different non-timber forest products (NTFPs) has been undervalued. But in recent decades, interest has grown in uses of NTFPs as alternatives or supplements of forest products, which are important for economic purpose of the local forest dwellers. ${ }^{3} 456$ Now-a-days in few forests areas, during afforestation, some fruit yielding species, medicinal plant species are being planted as a policy decision. Plantation of these tree species are done to enhance diversity and heterogeneity in the tree level. Today establishment of new forest has been increased remarkably. ${ }^{78}$ Since 1990 in India, as well as in West Bengal a major portion of the natural coppice sal forest is protected by concerned Forest Protection Committee (FPC) through Joint Forest Management (JFM), which was previously in a degraded condition and maintained by the State Forest Department. ${ }^{10}$ There are the great differences of natural forest from a plantation ecosystem regarding the vegetation dynamics, structure and function also. ${ }^{11}$ The quality and quantity of undergrowth depends on the tree canopy and the edaphic and microclimatic conditions existing under the particular type of forest. ${ }^{12}$ The nature of ground flora, its diversity and density vary with the type of forest community. ${ }^{13}$ The proportion of species to genera were 13:1 in world, 7:1 in India and 1.5:1 in Amarkantak, Madhya Pradesh, India. ${ }^{14}$ It indicates that every genus is of great botanical importance in any plant community. The species diversity, density and nature of vegetation vary with the type of forest. ${ }^{15}$

In this study the vegetation and nutrient composition of a sal dominated stand (natural forest) was compared with that of eucalyptus stand (plantation) in Paschim Midnapore district. The forest of Paschim
Midnapore district is truly unique, which shows higher species diversity. ${ }^{16,17}$ As per Champion and Seth's classification of Forest Type of India, the study area comes under Major Group - II, i.e. "Dry Tropical Forest". 18

\section{Study Area}

The study was done in Bhagabatichak forest area under Midnapore East Forest Division, West Bengal. This area has two type of stands, such as coppice sal stand (CSS) and coppice eucalyptus stand (CES), which are adjacent to each other. Sal stand was jointly managed by FPC and Forest Department, whereas eucalyptus stand was under management of Forest Department. In CES eucalyptus plantation was done by Forest Department. Bhagabatichak village is $8 \mathrm{~km}$ away from Midnapore town of Paschim-Midnapore District, where FPC has existed for the last 25 years. The area of the coppice sal (Shorea robusta) stand is 61 hectares and the area of the eucalyptus stand is 33 hectares. Bhagabatichak forest belongs to the latitude $22.4614^{\circ} \mathrm{N}$ and longitude $87.2780^{\circ} \mathrm{E}$. The annual rainfall of this site is $1580 \mathrm{~mm}$ of which $80 \%$ is precipitated at the end of June to September. The mean minimum and maximum temperature ranges from $15.6^{\circ} \mathrm{C}$ to $37.8^{\circ} \mathrm{C}$.

\section{Material and Methods}

The phyto-sociological observations in both stands were recorded every month during 2019 -20 using quadrat method. ${ }^{15}$ The data were represented in pre-monsoon, monsoon and post-monsoon seasons. Pre-monsoon represents March to June, monsoon July to October and post-monsoon November to February.

\section{Layout of sample plots}

"Species area curve" method was used to determine the minimum size and minimum number of the quadrats. ${ }^{19}$ To study the plant communities quadrats of $(10 \mathrm{~m} \times 10 \mathrm{~m})$ for tree species, $(5 \mathrm{~m} \times 5 \mathrm{~m})$ for shrubs and $(1 \mathrm{~m} \times 1 \mathrm{~m})$ for herbs were selected randomly. Ten quadrats of each (tree, shrub and 
herb) were studied in both the stands. Quadrat wise plant species were encountered, listed and then identified with the help of floristic study of regional vegetation by Prain. ${ }^{20}$ The identifications were cross checked with the help of Bennet21. Different phytosociological parameters were measured as follows-

Table 1: Number of Plant Species in CSS and CES

\begin{tabular}{|c|c|c|c|c|c|c|c|}
\hline & \multicolumn{4}{|c|}{ Coppice Sal Stand (CSS) } & \multicolumn{3}{|c|}{ Coppice Eucalyptus Stand (CES) } \\
\hline & Pre & -monsoon & Monsoon & Post -monsoon & Pre-monsoon & Monsoon & Post -monsoon \\
\hline Tree species & & 15 & 15 & 15 & 9 & 11 & 10 \\
\hline \multicolumn{2}{|c|}{ Shrubs \& climbers } & 17 & 22 & 22 & 10 & 13 & 11 \\
\hline \multicolumn{2}{|c|}{ Herbs \& grasses } & 16 & 34 & 30 & 12 & 19 & 15 \\
\hline \multicolumn{2}{|l|}{ TOTAL } & 48 & 71 & 67 & 31 & 43 & 36 \\
\hline
\end{tabular}

Importance Value Index $(I V I)-\quad I V I=R_{D}+R_{A}+R_{F}^{22}$

Where, $R_{D}=$ Relative Density, $R_{A}=$ Relative Abundance and RF= Relative Frequency.

Diversity Index $\left(\mathbf{H}^{\prime}\right)=-\sum\left\{\left(\frac{n i}{N}\right) \log \left(\frac{n i}{N}\right)\right\}^{23}$,

where, $\mathrm{ni}=\mathrm{IVI}$ of individual species and $\mathrm{N}=\mathrm{IVI}$ of all the species.

Concentration of Dominance $(\mathrm{Cd})$ - It was measured by Simpson's Index, ${ }^{24} \mathrm{Cd}=\sum(\mathrm{ni} / \mathrm{N})^{2}$, where, $\mathrm{ni}=\mathrm{IVI}$ of individual species and $\mathrm{N}=\mathrm{IVI}$ of all the species

Species Richness Index (d) - d = S -1/ log N25 where, $\mathrm{S}=$ Total number of species, $\mathrm{N}=\mathrm{IVI}$ of all the species.

Beta Diversity $(\beta d)-\beta d=S c / S^{26}$, where, $S c=$ total number of species in all the sites and $S=$ average species per site.

Index of Similarity (IS) or Quotient of Similarity (QS) - This was calculated by the formula of Sorensen, ${ }^{27}$ which was described by Muller-Dombois and Ellenberg. ${ }^{28}$ IS or QS $=2 \mathrm{c} / \mathrm{a}+$ $b$, Where, $a=$ Total number of plant species in one stand, $b=$ Total number of plant species in another stand, $c=$ Total number of plant species in both the stand.

Biomass - The above ground biomass were collected by destructive method. Destructive sampling of different species was done thrice (pre-monsoon, monsoon and post-monsoon). Species wise dry biomass estimated after drying the sample in Hot air oven at $80^{\circ} \mathrm{C}$ for 24 hours.

Nutrient Composition - For assessing composition of flora, the plants from all the quadrats were harvested, identified and sorted out into dominant, co-dominant and other associated species by their occurrence/frequency in the forest. The vegetation was weighed, chopped, dried at $60^{\circ} \mathrm{C}$, re-weighed, grind to fine power and analyzed for nitrogen, phosphorus, and potash. ${ }^{29}$

Soil pH - The pH meter is used to measure the soil $\mathrm{pH}$, with the help of glass electrodes in 1: 1.25 of soil: water.

\section{Result and Discussion}

In a place the plant community nature is depend upon the plant species which grow and develop in this environment. ${ }^{30}$ The variation of community composition between the two adjacent coppice stands and the effect of dominant tree species on other species were studied. The study reveals that more plant species were present in coppice sal stand (CSS) than coppice eucalyptus stand (CES). The numbers of tree and shrubs species were more or less the same in all three seasons in both the study sites (Table-1), but in case of herbs many species regenerate during monsoon period, which are not available in other seasons (Table-1). Maximum numbers of plant species were available in monsoon period, 71 in CSS, among them 15 tree species, 


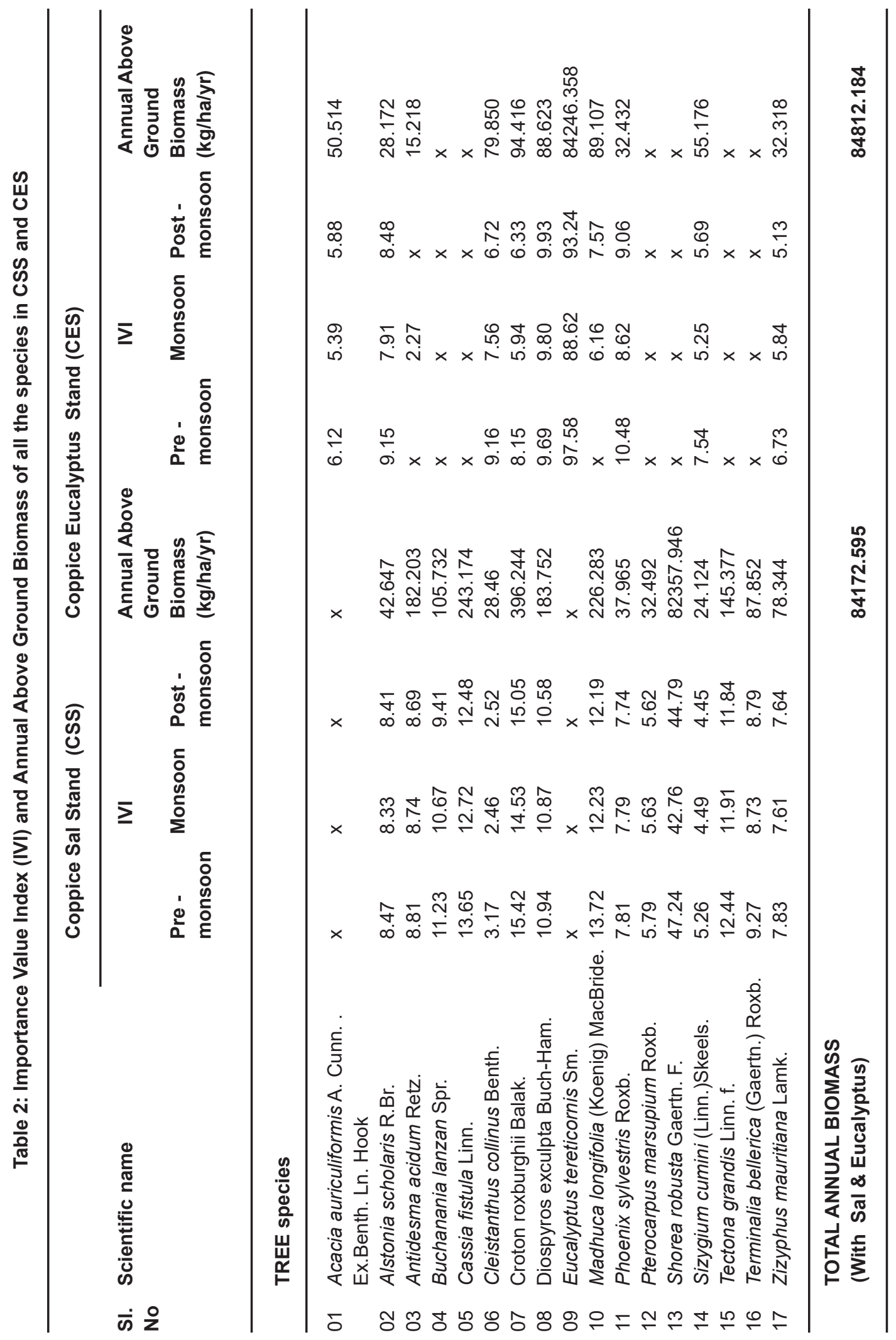




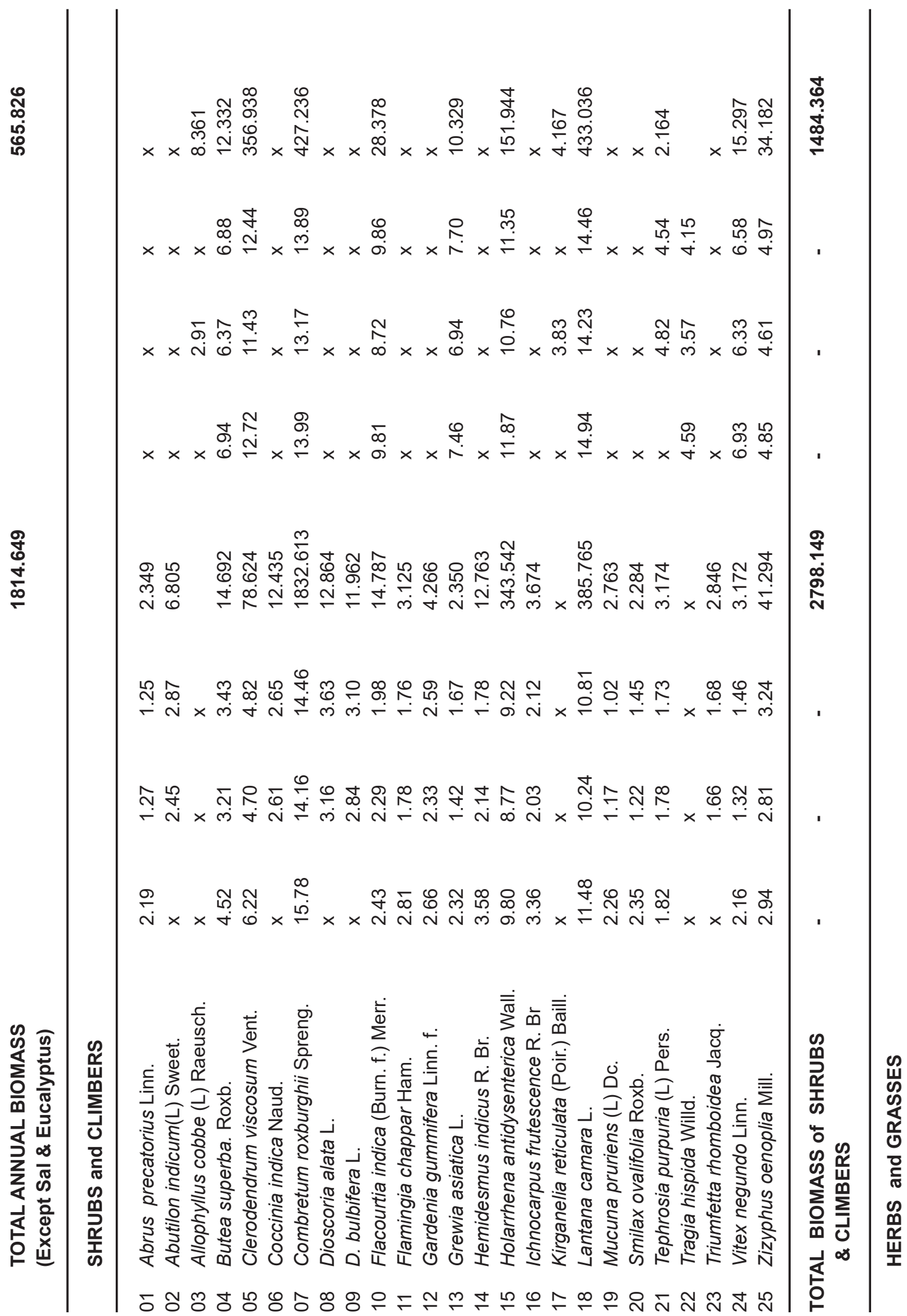




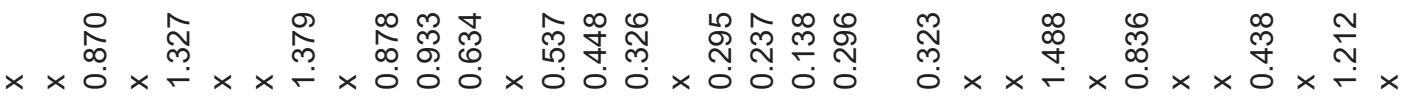

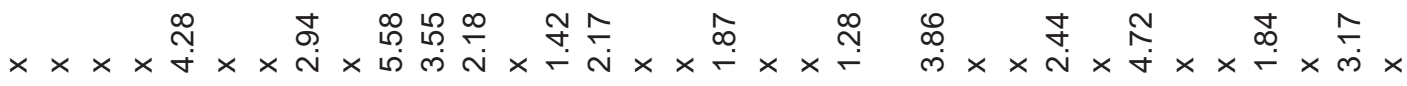

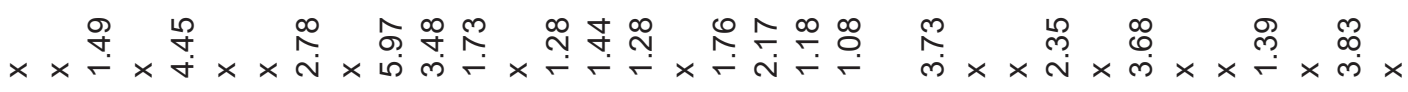

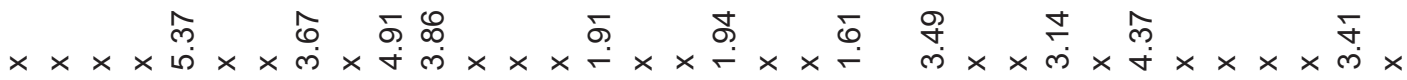

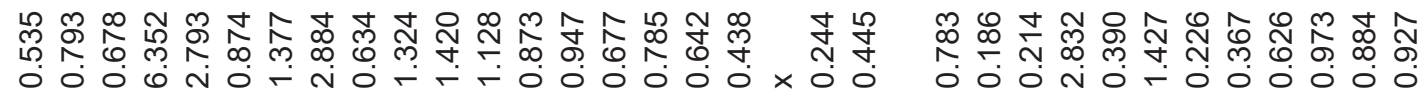

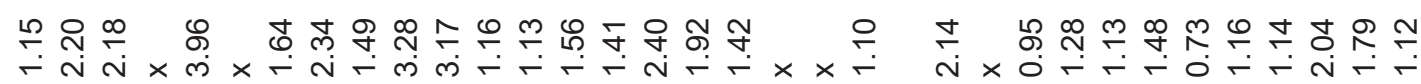

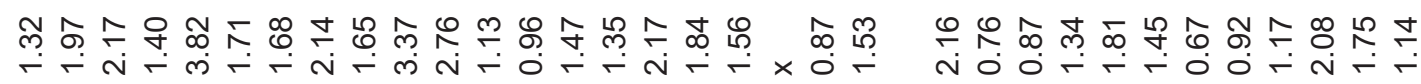

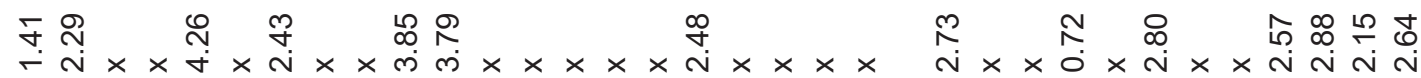

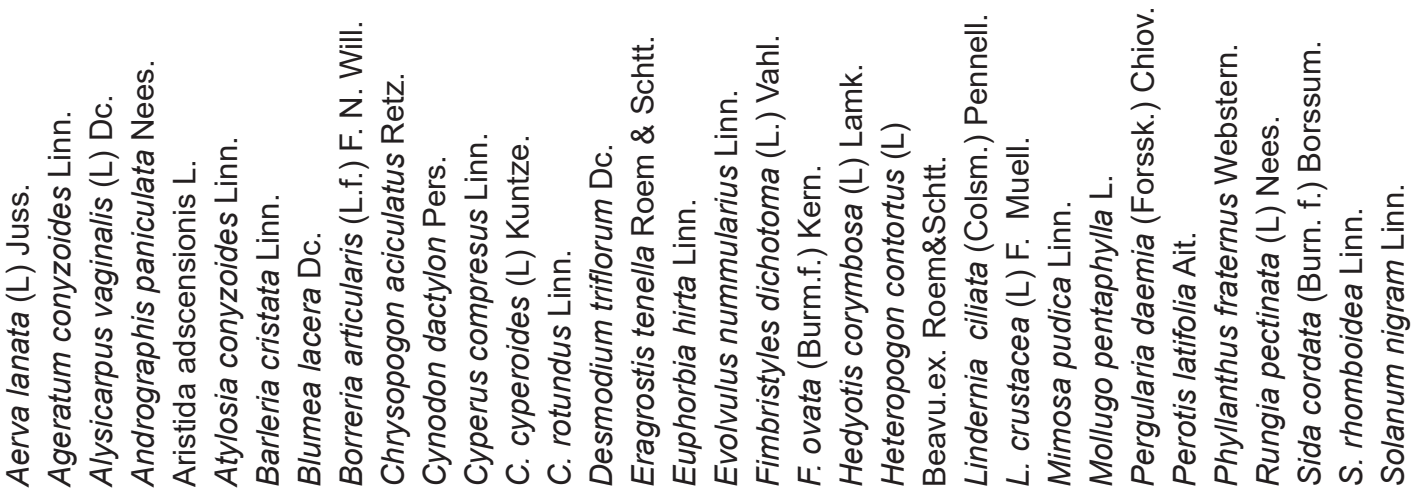

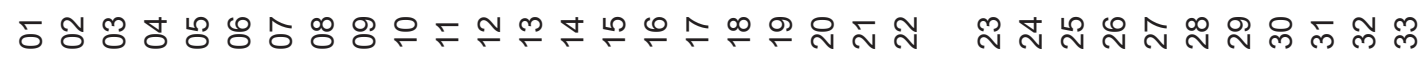




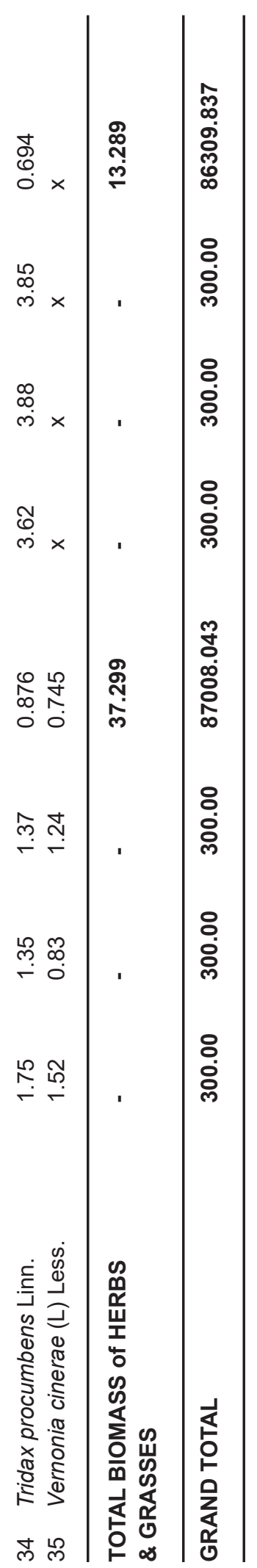

22 shrubs and climbers, 34 herbs and grasses. Whereas during monsoon period the total number of plant species in CES were only 43, among them 11 tree species, 13 shrubs and climbers, 19 herbs and grasses (Table-1). Similar observations were recorded in natural coppice sal forest and akashmoni (Acacia auriculiformis A. Cunn. Ex. Benth. Ln. Hook.) plantation stand of Paschim-Minapore district of West Bengal. ${ }^{31}$ Several authors were noted that the variations of vegetation are depends upon several factors like species composition and structure,$^{32}$ management strategies,,$^{33}$ soil moisture and nutrient dynamics, ${ }^{34,35}$ succession history ${ }^{36}$ and fragmentation. ${ }^{37}$ Occurrence of maximum number of plant species (71) in CSS shows its status as climatic climax, besides this, the stand is protected by FPC, so the disturbances were least. In CES the total number of species (43) was too much less than CSS during monsoon period, where the different disturbances like thinning, pruning, cutting, collection of fuel wood, grazing are too much high, so the number of species is too much less.

IVI of a plant community represents the ecological importance of a species in the community. In CSS highest IVI was occupied by sal in all the seasons (Table- 2), during monsoon this was followed by Croton roxburghii (14.53), then Combretum roxburghii (14.16). Similarly in CES highest IVI was occupied by eucalyptus in all the seasons (Table- 2), during monsoon E. tereticornis was followed by Lantana camara (14.23) and Combretum roxburghii (13.17) which are listed in Table-2. The result also shows that in between the sal and eucalyptus maximum IVI was occupied by eucalyptus in CES than the sal in CSS. It indicates the effectiveness of major species on other species was more by eucalyptus than sal. On the basis of the "Kath and Kukath" concept the FPC protects the forest specially the sal tree. But recent days different NTFPs are used and sold in the market, which support the economy of the forest people. So they protect the forest as a whole, which promote the conservation of forest. Similar findings were observed by some authors. ${ }^{2,} 6$ The village people irregularly collect the different tree species (except sal) as fuel wood. These tree species remain in sapling condition throughout the year. Another dominant species like, Combretum roxburghii, Holarrhena antidysenterica and L. camara remain constant and showed better growth in CSS. Whereas in CES 
the grazing and cutting of different plant species (except eucalyptus) were done continuously, no restrictions were there. Though in CES Combretum roxburghii, C. viscosum, L. camara, constantly present but not in better condition as in CSS.

Table: 3 Different phytosociological parameters of CSS and CES

\begin{tabular}{lcccccc}
\hline & \multicolumn{3}{c}{ Coppice Sal Stand (CSS) } & \multicolumn{2}{c}{ Coppice Eucalyptus Stand (CES) } \\
\cline { 2 - 7 } & $\begin{array}{c}\text { Pre- } \\
\text { monsoon }\end{array}$ & Monsoon & $\begin{array}{c}\text { Post- } \\
\text { monsoon }\end{array}$ & $\begin{array}{c}\text { Pre- } \\
\text { monsoon }\end{array}$ & Monsoon & $\begin{array}{c}\text { Post- } \\
\text { monsoon }\end{array}$ \\
\hline Total no. of species & 48 & 71 & 67 & 31 & 43 & 36 \\
Diversity Index(H/) & 1.488 & 1.983 & 1.723 & 1.228 & 1.327 & 1.274 \\
Dominance Index (Cd) & 0.048 & 0.042 & 0.044 & 0.125 & 0.106 & 0.113 \\
Species Richness Index (d) & 18.974 & 28.259 & 26.645 & 12.112 & 16.956 & 14.129 \\
$\beta$ Diversity & 1.215 & 1.245 & 1.300 & 0.784 & 0.754 & 0.699 \\
Similarity Index & & & & & & \\
(During monsoon) & $64.91 \%$ & & & & & \\
\hline
\end{tabular}

Vegetation analysis and distribution patterns of this study are as follows, the diversity index $\left(\mathrm{H}^{\prime}\right)$ and concentration of dominance $(\mathrm{Cd})$ were calculated on the basis of density and IVI. The information of species richness, distribution and the rate of change in species composition were available from diversity index. The ecosystem process is controlled by the strong function of the structure and diversity of vegetation. Diversity index is an important attribute of an organized community. ${ }^{38}$ The diversity index $(\mathrm{H} /$ ) was maximum in CSS during monsoon (1.983) and minimum in CES during pre-monsoon (1.228). It indicates that more species were observed in CSS (Table-2). In case of herbs the open canopy indicates the species richness and composition of an ecosystem. ${ }^{39}$ The study reveals that higher species richness values (d) were observed in CSS during all the seasons, among them, the highest was in monsoon (28.259). The lower species richness value were observed in CES throughout the year, among them lowest in pre-monsoon (12.112). In Chendra teak forest of Dhaurpur range in Sarguja district, Chhattisgarh, India, the Shannon diversity index value and species richness value for shrubs of a natural forest was double than the plantation sites of teak. ${ }^{11}$ The values of concentration of dominance (Cd) i.e. dominance index were maximum in CES and minimum in CSS in all the seasons, which are shown in Table- 3 . Eucalyptus is a quick growing, large woody, gigantic tree species and the coppicing power is high, so the ecological success of the associated species was found to be very low in terms of their competing ability and therefore the ground vegetation was also found to be very thin. The adaptability and the coppicing ability of eucalyptus are better in lateritic region, a common soil type of the study region40. But sal is a slow growing species and it has no harmful effect on another plant species. The plant diversity was higher in CSS, this was also supported by several authors. ${ }^{41,42}$

$\beta$ diversity reflects the rate of species change in the plant communities. It was more in CSS and less in CES, shown in Table-3. It shows highest stability in CSS in comparison to CES. Some authors has quoted that diversity generates community stability, dominance generates community productivity and increasing the number of species in a forest stand rather enhancing efficiency though more exploitation of site resources decreases efficiency perhaps through competition. ${ }^{43,44}$ Greater diversity provides a number of pathways in the ecosystem's functioning which gives stability to the ecosystem.

The similarity index (IS) is $64.51 \%$, because CSS and CES are situated side by side at the same locality. Though these two stands are situated side by side, but the vegetation was different, due to the effect of dominant species on other species, such as in CSS sal shares the competition with other species but in CES, eucalyptus suppresses the other species. ${ }^{45}$ Due to the different effectiveness 
of dominant species on other plant species the similarity of these two stands was not higher.

Comparative study of annual above ground biomass (agb) of the two stands shows that the total annual agb was slightly higher in CSS $(87008.043 \mathrm{~kg}$ $\left.\mathrm{ha}^{-1} \mathrm{yr}^{-1}\right)$ than CES (86309.837 $\left.\mathrm{kg} \mathrm{ha}^{-1} \mathrm{yr}^{-1}\right)$. The difference of agb was (87008.043 - 86309.837) $698.206 \mathrm{~kg} \mathrm{ha}^{-1} \mathrm{yr}^{-1}$. But in tree species the individual agb was more in eucalyptus (84246.358 kg ha-1 $\mathrm{yr}^{-1}$ ) than sal $\left(82357.946 \mathrm{~kg} \mathrm{ha}^{-1} \mathrm{yr}^{-1}\right)$. This is due to the fact that eucalyptus is a fast growing species than sal. In CSS the total agb (except sal) was 4650.07 $\mathrm{kg} \mathrm{ha}^{-1} \mathrm{yr}^{-1}$. Similar finding was recorded by Sahoo46. Sahoo enumerated the total agb (except sal) in Chandra natural coppice sal forest of Midnapur East Forest Division in West Bengal was 5932.01 $\mathrm{kg} \mathrm{ha}^{-1} \mathrm{yr}^{-1}$ which was quite less in respect of the total annual agb. In CSS the total agb was 87008.043 $\mathrm{kg} \mathrm{ha}^{-1} \mathrm{yr}^{-1}$, among this, tree species (except sal) contributed only $2.08 \%$ (1814.649 $\left.\mathrm{kg} \mathrm{ha}^{-1} \mathrm{yr}^{-1}\right)$, shrubs and climbers 3.21\% (2798.122kg ha-1 $\left.\mathrm{yr}^{-1}\right)$, herbs and grasses $0.04 \%$ (37.299 kg ha-1 $\left.\mathrm{yr}^{-1}\right)$. The rest amount $94.67 \%$ (82357.946 kg ha-1 $\left.\mathrm{yr}^{-1}\right)$ was contributed by sal only, because sal is the most dominant tree species in this stand, besides this sal is protected by FPC. In CES the total agb was $86309.837 \mathrm{~kg}$ $\mathrm{ha}^{-1} \mathrm{yr}^{-1}$, among this, tree species (except eucalyptus) has only $0.65 \%\left(565.826 \mathrm{~kg} \mathrm{ha}^{-1} \mathrm{yr}^{-1}\right)$, shrubs and climbers $1.72 \%\left(1484.364 \mathrm{~kg} \mathrm{ha}^{-1} \mathrm{yr}^{-1}\right)$, herbs and grasses $0.02 \%\left(13.289 \mathrm{~kg} \mathrm{ha}^{-1} \mathrm{yr}^{-1}\right)$ and only eucalyptus contribute $97.61 \%(84246.358 \mathrm{~kg}$ ha $\left.{ }^{1} \mathrm{yr}^{-1}\right)$. Eucalyptus was the dominant tree species in CES. The result shows that the individual agb was more in eucalyptus than sal. With respect to total annual agb, species diversity and stability, the CSS was performed better, more significant and more stable than CES. In CES eucalyptus suppress the growth of other species and allelochemicals secreted by eucalyptus which prevents the germination and growth of other species. Similar findings were observed by several authors. ${ }^{47,45}$

Table 4: Analytical composition of major plants of CSS and CES

Analytical Composition of Above Ground Biomass

Coppice Sal Stand (CSS) Coppice Eucalyptus Stand (CES)

\section{SI. No. Scientific Name $\quad$ Av. N (\%) Av. P (\%) Av. K (\%) Av. N (\%) Av. P (\%) $\quad$ Av. K (\%)}

\begin{tabular}{|c|c|c|c|c|c|c|c|}
\hline \multicolumn{8}{|c|}{ Tree / Sapling } \\
\hline 01 & Madhuca longifolia & 0.761 & 0.394 & 1.324 & 0.685 & 0.317 & 1.278 \\
\hline 02 & Croton roxburghii & 0.747 & 0.438 & 1.762 & 0.597 & 0.358 & 1.159 \\
\hline \multicolumn{8}{|c|}{ Shrubs and climbers } \\
\hline 03 & Clerodendrumviscosum & 0.874 & 0.418 & 1.473 & 0.783 & 0.412 & 1.382 \\
\hline 04 & Combretum roxburghii & 1.272 & 0.527 & 1.867 & 0.864 & 0.513 & 1.724 \\
\hline 05 & Holarrhenaantidysenterica & 0.856 & 0.422 & 1.383 & 0.628 & 0.329 & 1.247 \\
\hline 06 & Lantana camara & 0.879 & 0.515 & 1.642 & 0.835 & 0.487 & 1.686 \\
\hline \multicolumn{8}{|c|}{ Herbs and grasses } \\
\hline 07 & Alysicarpusvaginalis & 0.873 & 0.313 & 1.217 & 0.768 & 0.280 & 0.936 \\
\hline 08 & Aristida adscensionis & 0.792 & 0.349 & 0.946 & 0.728 & 0.311 & 0.876 \\
\hline 09 & Chrysopogonaciculatus & 0.637 & 0.288 & 0.917 & 0.624 & 0.228 & 0.836 \\
\hline
\end{tabular}

\section{Nutrient Composition of Major Species}

The major species having higher IVI and common to both the stands were selected for performing nutrient composition analysis, which are listed in Table-4. Their respective contribution towards production of biomass and nutrient uptake revealed that in both the stands higher nutrients (available
NPK) were observed in Combretum roxburghii. In CSS available NPK were $1.272 \%, 0.527 \%$ and $1.867 \%$. In CES the available NPK values were $0.864 \%, 0.513 \%$ and $1.724 \%$ in the same species. Next to Combretum roxburghii more nutrients were observed in L. camara (Table-4). In L. camara more nutrients (available NPK) were observed in CSS 
than the CES. A similar trend was observed for other species (Table-4). Nutrient uptake efficiency was more in the species of CSS, though sal had optimum expression on these sites. Available NPK were less in the species of CES, these are due to the fact that this stand is open to biotic interference by the local people and considerable amount of understory vegetation is being removed by villagers leading to sparse understory. ${ }^{11}$

Table 5: Soil pH of CSS and CES

\begin{tabular}{lccccccc}
\hline & & $\mathbf{1}$ & $\mathbf{2}$ & $\mathbf{3}$ & $\mathbf{4}$ & $\mathbf{5}$ & Mean \\
\hline Coppice Sal Stand (CSS) & Top Soil (0-15)cm & 5.12 & 5.73 & 5.48 & 5.67 & 5.65 & 5.53 \\
& Sub Soil $(15-30) \mathrm{cm}$ & 5.54 & 5.92 & 5.82 & 5.81 & 5.88 & 5.79 \\
Coppice Eucalyptus Stand (CES) & Top Soil (0-15)cm & 5.06 & 4.87 & 4.68 & 5.12 & 4.70 & 4.88 \\
& Sub Soil $(15-30) \mathrm{cm}$ & 5.18 & 4.90 & 4.83 & 5.38 & 4.84 & 5.02 \\
\hline
\end{tabular}

Mean $\mathrm{pH}$ value of soil in CSS was 5.53 in top soil $(0-15 \mathrm{~cm}$.) and 5.79 in subsoil $(15-30 \mathrm{~cm}$.). The corresponding mean $\mathrm{pH}$ value of soil in CES was 4.88 in top soil and 5.02 in subsoil. In the lateritic region of West Bengal the soil $\mathrm{pH}$ under coppice sal forest ranges from 5.0 to 6.6 , which are acidic to nearly neutral in reaction. ${ }^{48}$ Under neutral $\mathrm{pH}$ conditions, rapid transformation, low fixation and efficient extraction of available phosphorus in sal forest soil is more than eucalyptus forest soils. ${ }^{49}$

\section{Conclusion}

The results indicate that the availability and growth of the floral diversity in CSS is more than that of CES. There may be various factors to explain but most important one is the management of the stands. Most of the ecological factors like soil, water regime etc. being same, the dominant tree species of the stands are observed to be the drivers of community structure. Thus, it may be concluded that the sal stand is more stable as compared to the eucalyptus stand. These observations get credence from the fact that sal stand are more stable having better floral composition than the floral composition of eucalyptus stand, which can provide better welfare to human beings and more significant to human life.

\section{Acknowledgement}

I am grateful to Dr. S. K. Banerjee, DSc. Senior Scientist (Retd.), TFRI, Jabalur, MP and Dr. T.K. Mishra, Principal (Retd.), Vidyasagar College, Kolkata, West Bengal, for their guidance and encouragement in this research work. Thanks to all the villagers of Bhagabatichak, those who helped in different ways during the field work.

\section{Funding}

There is no funding or financial support for this research work.

\section{Conflict of interest}

There is no conflict of interest in the manuscript.

\section{References}

1. Uglade L, Perez O. Mean Annual Volume Increment of Selected Industrial Forest Plantation Species. Working Paper FP/I, FAO, Rome (Italy), 2001.

2. Shackleton C M, Shackleton S E. The Importance of Non-timber Forest Products in Rural Livelihood Security and as Safety Nets: A Review of Evidence from South Africa. S. Afr. J. Sci., 2004; 100(12): 658 - 664.

3. Sarmah R. Non-timber Forest Products:
Extraction and Impact on Plant Community Structure in and Around Namdapha National Park of Arunachal Pradesh, India. Indian J. of Plant Sci. 2012; 1(2- 3): 192 - $207 . \quad$ ISSN: 2319 - 3824 (online).

4. Dattagupta S, Gupta A, Ghose M. Non-timber Forest Products of the Inner Line Reserve Forest, Cachar, Assam, India: Dependency and Usage Pattern of Forest-dwellers. Assam Univ. J. Sc. Technol., 2010; 6(1):21 - 27. 
5. Malik R H. Sustainable Management of Nontimber Forest Products in Orissa: Some Issues and Optics. Indian J. Agric. Econ., 2000; 55:384 $-397$.

6. Mahapatra A. Alberts H, Robinson E. The Impact of NTFP Sales on Rural Households' Cash Income in India's Dry Deciduous Forest. Environ. Manag., 2005; 35: 258 - 265.

7. Kumar A, Dash D, Jharia M K. Impact of Rhizobium on Growth, Biomass Accumulation and Nodulation in Dalbergia sissoo Seedlings. The Bioscan, 2013; 8(2):553 - 560.

8. Kumar A, Dash D, Jharia M K. Influence of Rhizobium Inoculation on N,P and K Content in Dalbergia sissoo Roxb. Ecol. Environ. Conserv. 2014; 20(3): 1059- 1065.

9. Sinha R, Yadav D K, Jhariya M K. Growth Performance of Sal in Mahamaya Central Forest Nursery (Ambikapur), Chattisgarh. Int. J. Sci. Res. 2014; 3(11): 246 - 248.

10. Sahoo T. K. Ecological Impacts of Joint Forest Management (JFM) - in Midnapur Region of South West Bengal. PhD Thesis. FRI, Dehradun. 2002; 9 - 45.

11. Jhariya M. K, Yadav D. K. Understorey Vegetation in Natural and Plantation Forest Ecosystem of Sarguja (C. G.), India, J.A. N.S. 2016; 8 (2): 668 - 673.

12. Rajvanshi R, Kumar V, Bachpai W, Rajgopal K, Raj S.F.H. Herbaceous Undergrowth in Some Forest Habitats in Nilgiris. Indian Forester 1987; 113(9): 599- 608.

13. Pandey P. K, Bisht A. P. S, Sharma S. C. Comparative Vegetation Analysis of Some Plantation Ecosystems. Indian For. 1988; 114 (7): $379-389$.

14. Buch, M. N. The Forest of M P. Bhopal: Madhya Pradesh Madhyan; 1991, 132 - 137.

15. Shadangi D K, Nath V. Impact of Seasons on Ground Flora under Plantation and Natural Forest in Amarkantak. Indian For. 2005; 131(2): $240-250$.

16. Das D, Ghosh P. Ecological Studies of Ecosystem Health Indicators at Nayagram of Paschim Medinipur District in Lateritic Forest of South West Bengal, India. JESTFT, 2014; $8(6): 48-63$.

17. Das D. Vegetation Spectrum and Natural Beauty of Bhadutala Forest in West Bengal, India. IJSART, 2017; 3 (10): 25 - 38.

18. Champion H. G, Seth S. K. Forest Types of
India. Delhi: Manager Publications; 1968.

19. Oosting $\mathrm{H}$. J. The Study of Plant Communities. USA: W. H. Freeman and Co.; 1958, 43- 46.

20. Prain D. Bengal Plants, Vol.-I and Vol.-II. Dehradun, India: Bishen Singh and Mahendra Pal Singh; 1903.

21. Bennet S.S.R. Name Changes of Flowering Plants of India and Adjacent Region. Dehradun, India: S. Selvaraja, Triseas Publishers; 1987.

22. Curtis J. T. The Vegetation of Wisconsin University, Wisconsin Press, Madison. Ecology. 1959; 44: 678 - 697.

23. Shannon C. E, Wiener W. The Mathematical Theory of Communication Univ. Illinois Press, Urbana, 1963.

24. Simpson E. H. Measurement of Diversity. Nature. 1949; 163: 688 - 699.

25. Margalef R. Perspective in Ecological Theory. Chicago: University of Chicago Press; 1958.

26. Whittaker R. H. Evolution and Measurement of Species Diversity. Taxon 1972; 21: 213 - 251.

27. Soreson T. Kongelige Danske Videnskabernes Selskab. A Method of Establishing Groups of Equal Amplitudes in Plant Sociology Based on Similarity of Species Content and its Application to Analyses of the Vegetation on Danish Commons. Biologiske Skrifter, 1948; 5: 1 - 34.

28. Muller-Dombois D, Ellenberg H. Aims and Methods of Vegetation Ecology. New York: John Willey and Sons Inc; 1974.

29. Jakson M. L. Soil Chemical Analysis. Printice Hall Inc. Englewood Cliffs, N. J. 1967.

30. Bliss L. C. Alpine Plant Communities of the Presidential Range, New Hampshire, 1963.

31. Sahoo T. K. Effect of Seasons on Ground Flora Under Plantation and in Natural Forest in South West Bengal, Ela Jour. For. Wild. 2021; 10(1):874- 885.

32. Sanger R, Singh A, Singh J. S. Differential Effect of Woody Plant Canopies on Species Composition and Diversity of Ground Vegetation: A Case Study. Trop. Ecol. 2008; 49: 189 - 197.

33. Hart S. A, Chen H. Y. H. Fire, Logging and Overstory Affect Understory Abundance, Diversity and Composition in Boreal Forest. Ecol. Monogr. 2008; 78: 123 - 140.

34. Siebert S. From Shade to Sun-grown Perennial Crops in Sulawesi, Indonesia: Implications for Biodiversity Conservation and Soil Fertility. Biodivers. Conserv. 2002; 11: 1889 - 1902.

35. Ramadhanil R, Tjitrosoedirdjo S. S, Setiadi D. 
Structure and Composition of Understorey Plant Assemblages of Six Land Use Types in the Lore Lindau National Park, Central Sulawesi, Indonesia. Bangladesh J. of Plant Taxon. 2008; 15: 1- 12.

36. La Frankie J. V, Ashton P.S, Chuyong G. B, Condit L. Co. R, Davies S. J, Foster R, Hubbell S.P, Kenfack D, Lagunzad D, Losos E. C, Nor N. S. M, Tan S, Thomas D. W, Valencia R, Villa G. Contrasting Structure and Composition of the Understory in Species-rich Tropical Rain Forest. Ecology, 2006; 87: 2298 -2305.

37. Rasingam L, Parthasarathy N. Diversity of Understory Plants in Undisturbed Tropical Lowland orests of Little Andaman Island, India. Biodivers. Conserv. 2009; 18: 1045 - 1065.

38. Hairston N. G, Smith F. E, Slobodkin L. D. Community Structure, Population Control and Competition. Am. Nat. 1964; 94.

39. Roberts M. R. Response of the Herbaceous Layer to Natural Disturbance in North American Forests. Can J. Bot. 2004; 82: 1273 - 1283.

40. Meher-Homji V. M. J. Indian Bot. Soc. 1971; 50: 162.

41. Banerjee S. K, Nath S, Mukherjee A, Namhata D. Ecological Status of Shorea robusta in Lateritic Region. Indian J. For. 1992; 15 (1): $33-43$.

42. Sahoo T. K, Banerjee S. K, Shukla P. K. Plant Diversity under Different Management Systems in a Lateritic Region of South West Bengal. Jour. Trop. For. 2020; 36 (III): 12- 27.

43. Lewis J. K. Primary Production in Grass Land Ecosystem U.S. / I.B.P. Grassland Ecosystem. Supplement. Ed. R. L. Dlx and R. C. Beidleman, 1970.

44. Mc. Naughton S.J. Relationship Among Functional Properties of California Grassland. Nature, 1967; 216:168- 169.

45. Chu C, Mortimer P E, Wang $H$, Wang $Y$. Allelopathic Effects of Eucalyptus on Native and Introduced Tree Species. For. Ecol. Manag. 2014; 323: 79 - 84.

46. Sahoo T. K. Ecological Impacts of Joint Forest Management (JFM) - in Midnapur Region of South West Bengal. PhD Thesis. FRI, Dehradun. 2002; 160 - 163.

47. Zhang C, Fu S. Allelopathic Effects of Eucalyptus and the Establishment of Mixed Stands of Eucalyptus and Native Species. Forest Ecol. Manage., 2009; 258(7): 1391 - 1396.

48. Banerjee S. K, Singh B, Nath S, Nandi A, Gangopadhyay S. K. Soil Charecteristics Under Coppice Sal (Shorea robusta) in the Lateritic Region of West Bengal. Indian Forester, 1989; 115 (10): $744-753$.

49. Narain $P$, Singh $R$, Singh K. Influence of Forest Covers on Physico-chemical and Site Characteristics in Doon Valley. Indian For., 1990; 116 (11): 901- 916. 